\title{
Recovery of microalgal biomass and metabolites: process options and economics
}

\author{
E. Molina Grima ${ }^{\text {a }}$ E.-H. Belarbi ${ }^{\mathrm{a}}$, F.G. Acién Fernández ${ }^{\mathrm{a}}$, \\ A. Robles Medina ${ }^{a}$, Yusuf Chisti ${ }^{\text {b,* }}$ \\ ${ }^{\mathrm{a}}$ Department of Chemical Engineering, University of Almeria, E-04071 Almeria, Spain \\ ${ }^{\mathrm{b}}$ Institute of Technology and Engineering PN456, Massey University, Private Bag 11 222, \\ Palmerston North, New Zealand
}

Received 27 May 2002; received in revised form 15 October 2002; accepted 15 October 2002

\begin{abstract}
Commercial production of intracellular microalgal metabolites requires the following: (1) largescale monoseptic production of the appropriate microalgal biomass; (2) recovery of the biomass from a relatively dilute broth; (3) extraction of the metabolite from the biomass; and (4) purification of the crude extract. This review examines the options available for recovery of the biomass and the intracellular metabolites from the biomass. Economics of monoseptic production of microalgae in photobioreactors and the downstream recovery of metabolites are discussed using eicosapentaenoic acid (EPA) recovery as a representative case study.

(C) 2002 Elsevier Science Inc. All rights reserved.
\end{abstract}

Keywords: Microalgae; Phaeodactylum tricornutum; Eicosapentaenoic acid; Process economics; Flocculation; Biomass recovery

\section{Introduction}

Microalgae can be used to produce numerous high-value bioactives (Borowitzka, 1986; Bubrick, 1991; Pulz et al., 2001; Li et al., 2001; Banerjee et al., 2002). Production of

* Corresponding author. Tel.: +64-6-350-5934; fax: +64-6-350-5604.

E-mail address: Y.Chisti@massey.ac.nz (Y. Chisti). 
microalgae-derived metabolites requires processes for culturing the alga (Ben-Amotz and Avron, 1987; Molina Grima, 1999; Molina Grima et al., 1999; Sánchez Mirón et al., 1999; Tredici, 1999; Borowitzka, 1999; Pulz, 2001; Pulz et al., 2001), recovery of the biomass, and further downstream processing to purify the metabolite from the biomass. As with many microbial processes for producing bioactives, the downstream recovery of algal products can be substantially more expensive than the culturing of the alga. This review examines some commercially relevant options for recovering microalgal products. A case study is used to illustrate the economics of recovery of eicosapentaenoic acid (EPA), an essential fatty acid from microalgae. EPA is an established neutraceutical and evidence is emerging for its therapeutic benefits in disease management (Peet et al., 2001, 2002).

\section{Production of microalgal biomass}

Production of microalgal biomass can be carried out in fully contained photobioreactors or in open ponds and channels. Open-culture systems are almost always located outdoors and rely on natural light for illumination (Terry and Raymond, 1985). Closed photobioreactors may be located indoors or outdoors (Sánchez Mirón et al., 1999; Pulz, 2001), but outdoor location is more common because it can make use of free sunlight. Design and operation of the microalgal biomass production systems have been discussed extensively (Terry and Raymond, 1985; Borowitzka, 1996; Pulz and Scheinbenbogen, 1998; Pulz, 2001; Pulz et al., 2001; Molina Grima, 1999; Molina Grima et al., 1999; Sánchez Mirón et al., 1999; Tredici, 1999). Here, we focus exclusively on issues relating with the harvest of the biomass and its downstream processing to recover intracellular metabolites.

\section{Recovery of biomass}

Harvesting of biomass requires one or more solid-liquid separation steps. Biomass can be harvested by centrifugation, filtration or in some cases, gravity sedimentation. These processes may be preceded by a flocculation step. Recovery of biomass can be a significant problem because of the small size $(3-30 \mu \mathrm{m}$ diameter) of the algal cells. Culture broths are generally relatively dilute $\left(<0.5 \mathrm{~kg} \mathrm{~m}^{-3}\right.$ dry biomass in some commercial production systems) and hence large volumes need to be handled to recover the biomass. No single harvest method may be suited to every case. Recovery of the biomass from the broth has been claimed to contribute $20-30 \%$ to the total cost of producing the biomass (Gudin and Therpenier, 1986).

Any suitable harvest method must be able to process the large volumes typical of algal biomass production processes. Filtrative recovery may be unsatisfactory because filtration can be relatively slow. For extremely low value products, gravity sedimentation, possibly enhanced by flocculation, may be the method of choice. Sedimentation tanks or settling ponds are generally used in biomass recovery from sewage-based processes (Venkataraman, 1978). Flocculation-flotation are also used (Shelef, 1978). Centrifugal recovery of the 
biomass is feasible for high-value products. Centrifuges can process large volumes relatively rapidly and the biomass can remain fully contained during recovery. A further consideration in selecting a suitable harvest method is the acceptable level of moisture in the product. Gravity sedimented sludge is generally more dilute than centrifugally recovered biomass. Too much moisture in the harvested biomass can substantially influence the economics of product recovery further downstream (Mohn, 1978), if dehydration of the biomass is required after harvest. Because thermal drying is more expensive than mechanical dewatering, thermal drying should be preceded by a mechanical dewatering step such as filtration or centrifugation. Some of the specific harvest methods are discussed next.

\subsection{Flocculation}

Various methods of flocculation can be used to aggregate the microalgal cells to increase the effective "particle" size and hence ease sedimentation, centrifugal recovery, and filtration (Elmaleh et al., 1991).

Microalgal cells carry a negative charge that prevents aggregation of cells in suspension. The surface charge can be neutralized or reduced by adding flocculants such as multivalent cations and cationic polymers to the broth. Ideally, the flocculants used should be inexpensive, nontoxic, and effective in low concentration. In addition, the flocculant should be selected so that further downstream processing is not adversely affected by its use.

Multivalent metal salts are effective flocculants or coagulants. The commonly used salts include ferric chloride $\left(\mathrm{FeCl}_{3}\right)$, aluminum sulfate $\left(\mathrm{Al}_{2}\left(\mathrm{SO}_{4}\right)_{3}\right.$, alum) and ferric sulfate $\left(\mathrm{Fe}_{2}\left(\mathrm{SO}_{4}\right)_{3}\right)$. The efficiency of electrolytes to induce coagulation is measured by the critical coagulation concentration, or the concentration required to cause rapid coagulation. Coagulation efficiency of metal ions increases with increasing ionic charge. Multivalent metal salts such as alum have been widely used to flocculate algal biomass in wastewater treatment processes (McGarry, 1970; Dodd, 1979; Benemann et al., 1980; Moraine et al., 1980; Koopman and Lincoln, 1983; Lincoln, 1985). Alum is an effective flocculant for Scenedesmus and Chlorella (Golueke and Oswald, 1965); however, flocculation by metal salts may be unacceptable if biomass is to be used in certain aquaculture and other applications.

Polyferric sulfate (PFS) is observed to be a better flocculant compared to the more traditional nonpolymerized metal salt flocculants (Jiang et al., 1993). Prepolymerized metal salts are effective over a wider $\mathrm{pH}$ range than nonpolymerized salts. Flocculation with prepolymerized metal salts is said to produce flocs that are easily dewatered. Efficiency of some flocculants for removing suspended cells of Anabaena and Asterionella is shown in Fig. 1.

An alternative to using metal salts is the use of cationic polymers (polyelectrolytes) (Tenney et al., 1969). In addition to reducing or neutralizing the surface charge on cells, the polymer flocculants can bring particles together by physically linking one or more particles through a process called bridging. Tenney et al. (1969) and Tilton et al. (1972) have demonstrated that the bridging mechanism also applies to flocculation of algal cells. Cationic polymers doses of between 1 and $10 \mathrm{mg} \mathrm{ml}^{-1}$ can induce flocculation of freshwater algae; however, a high salinity of the marine environment can inhibit flocculation by polyelectrolytes (Bilanovic et al., 1988). Effective flocculation with polyelectrolytes has been reported 

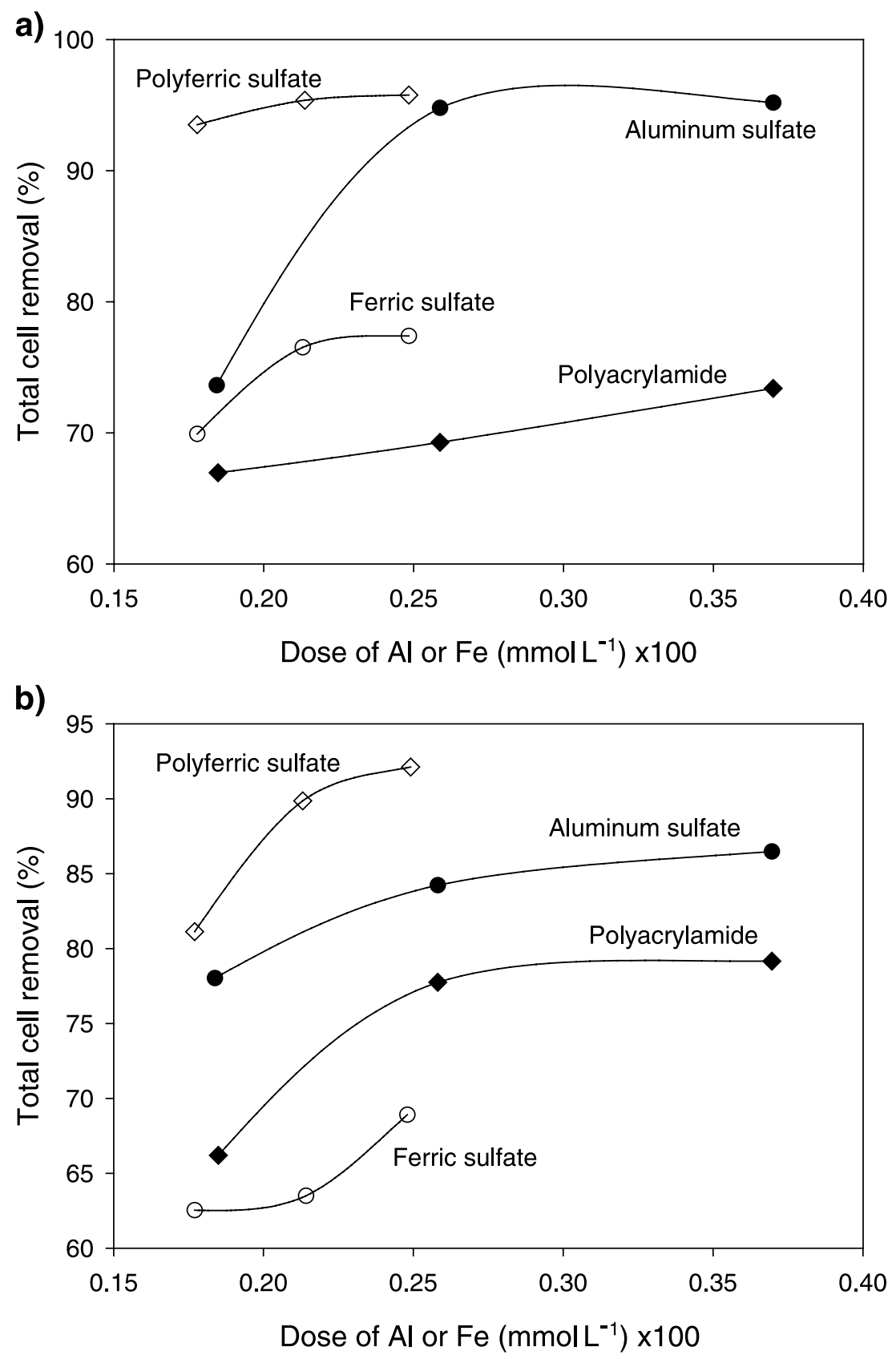

Fig. 1. A comparison of four coagulants for cell removal by flocculation of (a) Anabaena and (b) Asterionella (Jiang et al., 1993). 
at salinity of less than $5 \mathrm{~kg} \mathrm{~m}^{-3}$ (cf. salinity of seawater is $\sim 37 \mathrm{~kg} \mathrm{~m}^{-3}$ ). At high ionic strengths, cationic polymers tend to fold tightly and fail to bridge microalgal cells. The effect of ionic strength on flocculation of microalgae by some cationic polymers is shown in Fig. 2. In all cases, the flocculation was reduced by increasing ionic strength of the cell slurry.

The flocculation effectiveness of polyelectrolytes depends on many factors, including the molecular mass of the polymer, the charge density on the molecule, the dose used, the concentration of the biomass, the ionic strength and $\mathrm{pH}$ of the broth, and the extent of mixing in the fluid. Generally, high molecular weight polyelectrolytes are better bridging agents. Similarly, a high charge density tends to unfold the polymer molecule, improving its bridging performance and the ability to neutralize the surface change on cells. A high cell concentration in the broth helps flocculation, because the cell-cell encounters are more frequent in concentrated suspensions. A certain low level of mixing is useful as it helps bring the cells together; however, excessive shear forces can disrupt flocs (Chisti, 1999).

Polymeric flocculants have been used extensively for recovering microalgal biomass. However, in comparison with salts such as aluminum sulfate, cationic polyelectrolytes may be less effective (Pushparaj et al., 1993). Studies with Chlorella ellipsoidia at biomass concentration of $0.05-3 \mathrm{~kg} \mathrm{~m}^{-3}$ and polymer concentration of $1 \times 10^{-5}$ to $1 \mathrm{~kg} \mathrm{~m}^{-3}$ have shown an absence of flocculation at polymer concentration up to $0.2 \mathrm{~kg} \mathrm{~m}^{-3}$ (Tilton et al., 1972). Cationic polyethyleneimine is an effective flocculant for Chlorella. In studies with Chlorella, the amount of polymer required to initiate flocculation decreased as the molar mass of the polymer increased from 800 to about 2000 Da; however, further increases in molar mass did not improve flocculation efficiency. Changes in $\mathrm{pH}$ over the range of $\mathrm{pH} 4-7$, did

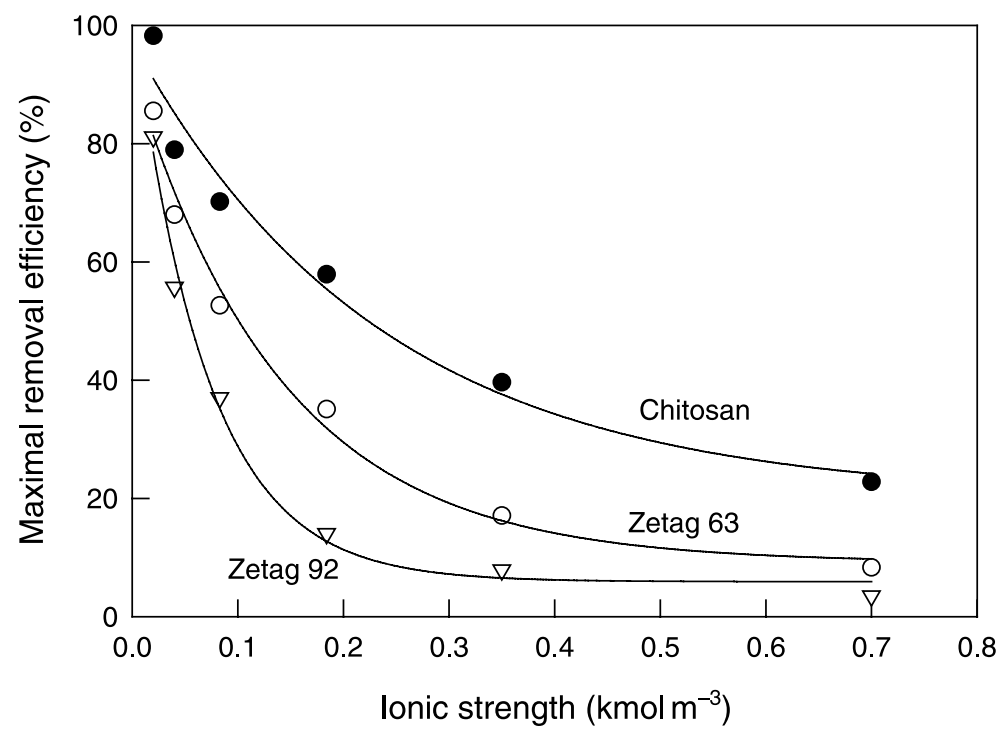

Fig. 2. The effect of ionic strength on efficiency of cell removal by flocculation with commercial polymers. The polymers tested included the cationic chitosan (400 kDa molar mass), Zetag 63 (a cationic polyacrylamide of $10,000 \mathrm{kDa}$ molar mass) and Zetag 92 (a cationic polyacrylamide of 20,000 kDa) (Bilanovic et al., 1988). 
not affect flocculation behavior (Tilton et al., 1972). In one study, Chlorella could be flocculated with a cationic polymer but not an anionic polymer (Cohen et al., 1957). Polyvalent organic polymers have been claimed as effective flocculants for Scenedesmus and Chlorella (Golueke and Oswald, 1965).

Chitosan, a polymer of acetylglucosamine, is an edible nontoxic flocculant that has proved effective with various microalgae (Nigam et al., 1980; Lavoie and de la Noue, 1983; Morales et al., 1985; Lubian, 1989). Chitosan is easily manufactured and requires low dosage rates (Richmond and Becker, 1986), but its flocculating power is reduced in salt water. Optimal flocculation dose of chitosan varies greatly. Optimal flocculation of Tetraselmis chui, Thalassiosira pseudonana and Isochrysis sp. has been observed at a chitosan dosage of 40 $\mathrm{mg}^{-1}$ (Heasman et al., 2000). In contrast, $150 \mathrm{mg}^{-1}$ of chitosan was required for optimal flocculation of Chaetoceros muellari (Heasman et al., 2000). There appears to be no consistent correlation between the taxonomic group of the algae and the quantity of chitosan needed for optimal flocculation (Heasman et al., 2000). Although chitosan is generally regarded as nontoxic, oyster larvae fed with chitosan-flocculated microalgae have shown a dramatically reduced survival (Heasman et al., 2000). Chitosan can be used as an entrapment matrix to immobilize microalgal biomass for use in tertiary treatment of wastewater (Kaya and Picard, 1996).

Sometimes, effective flocculation is achieved simply by changing the $\mathrm{pH}$ of the algal broth. In one study, extensive flocculation was achieved at $\mathrm{pH}$ values between 11.8 and 12 , without other added flocculants (McCausland et al., 1999). This method removed 95\% of the algal biomass from suspension and the sludge obtained had good settling characteristics and mechanical resistance. In other instances, extreme $\mathrm{pH}$ values can cause adverse effects. In a

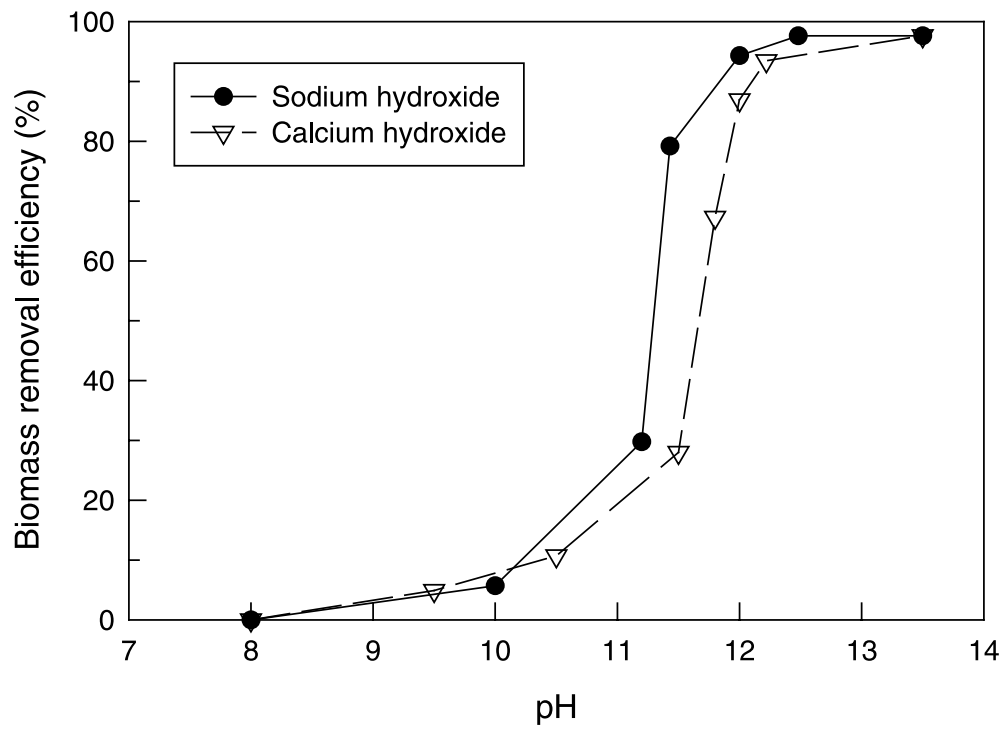

Fig. 3. Efficiency of cell removal by flocculation with alkalis. Data shown is for Chlorella at an initial biomass concentration of $180 \mathrm{mg} \mathrm{l}^{-1}$ (Yahi et al., 1994). 
study of EPA recovery from Skeletoma costatum, a pH of 10.2 sedimented $80 \%$ of the suspended cell mass but the cells lysed and released the intracellular contents (Blanchemain and Grizeau, 1999). Effect of two alkalis on cell removal by flocculation from suspensions of Chlorella is shown in Fig. 3 (Yahi et al., 1994).

Autoflocculation produced by modifying the culture medium, has been investigated for algal cultures in both fresh and seawater systems (Cannell, 1990; Suh et al., 1997; Lee et al., 1998). Also, bioflocculant produced by nonalgal microbial cultures have been assessed for flocculating microalgal cells (Hee-Mock et al., 2001). The bacterium Paenibacillus sp. AM49 is known to produce a bioflocculant that has proved effective for harvesting Chlorella vulgaris (Hee-Mock et al., 2001).

\subsection{Centrifugal recovery}

Most microalgae can be harvested from suspension by centrifugation. Centrifugal recovery methods are commonly treated in textbooks (Belter et al., 1988), but practical guidelines are rarely given. The guidelines provided by Chisti and Moo-Young (1991) for selection and use of centrifuges are especially relevant to recovery of microalgal biomass. Centrifugal recovery can be rapid, but it is energy intensive. Nevertheless, centrifugation is a preferred method of recovering algal cells (Benemann et al., 1980; Mohn, 1980; Richmond, 1986), especially for

Table 1

Comparison of some centrifugal methods of harvesting of microalgae (based on Mohn, 1980)

\begin{tabular}{|c|c|c|c|c|c|c|c|}
\hline $\begin{array}{l}\text { Machine } \\
\text { and make }\end{array}$ & $\begin{array}{l}\text { Operational } \\
\text { mode }\end{array}$ & $\begin{array}{l}\text { Concentration } \\
\text { method }\end{array}$ & Alga & $\begin{array}{l}\text { Suspended } \\
\text { solids (\%) in } \\
\text { concentrate } \\
\text { (concen- } \\
\text { tration } \\
\text { factor in } \\
\text { parentheses) }\end{array}$ & $\begin{array}{l}\text { Energy } \\
(\mathrm{kW} \mathrm{h}) \\
\text { consumed } \\
\text { per } \mathrm{m}^{3}\end{array}$ & $\begin{array}{l}\text { Relative } \\
\text { harvesting } \\
\text { cost }^{\mathrm{a}}\end{array}$ & Reliability \\
\hline $\begin{array}{l}\text { Self-cleaning, } \\
\text { disc-stack } \\
\text { centrifuge; } \\
\text { Westfalia }\end{array}$ & $\begin{array}{l}\text { Suspension } \\
\text { continuous; } \\
\text { concentrate } \\
\text { discontinuous }\end{array}$ & One step & $\begin{array}{l}\text { Scenedesmus, } \\
\text { Coelastrum } \\
\text { proboscideum }\end{array}$ & $12(120)$ & 1 & 1 & $\begin{array}{l}\text { Very } \\
\text { good }\end{array}$ \\
\hline $\begin{array}{l}\text { Nozzle } \\
\text { discharge } \\
\text { centrifuge; } \\
\text { Westfalia }\end{array}$ & Continuous & $\begin{array}{l}\text { For final } \\
\text { concentration or } \\
\text { for preconcen- } \\
\text { tration }\end{array}$ & $\begin{array}{l}\text { Scenedesmus, } \\
\text { C. proboscideum }\end{array}$ & $\begin{array}{l}2-15 \\
(20-150)\end{array}$ & 0.9 & 0.72 & Good \\
\hline $\begin{array}{c}\text { Decanter bowl } \\
\text { centrifuge; } \\
\text { Westfalia }\end{array}$ & Continuous & $\begin{array}{l}\text { For final } \\
\text { concentration } \\
\text { only to ca. } 2\end{array}$ & $\begin{array}{l}\text { Scenedesmus, } \\
\text { C. proboscideum }\end{array}$ & $22 \%$ & 8 & - & $\begin{array}{l}\text { Very } \\
\text { good }\end{array}$ \\
\hline $\begin{array}{l}\text { Hydrocyclones; } \\
\text { AKW }\end{array}$ & Continuous & $\begin{array}{l}\text { For preconcen- } \\
\text { tration }\end{array}$ & C. proboscideum & $0.4(4)$ & 0.3 & 9 & Poor \\
\hline
\end{tabular}

${ }^{a}$ Does not include labor. Relative harvesting costs are calculated on the basis of operational cost of a selfcleaning plate separator being 1.0 . 
producing extended shelf-life concentrates for aquaculture hatcheries and nurseries (D'Souza et al., 2000; Heasman et al., 2000).

The recovery of the biomass in a sedimenting centrifuge depends on the settling characteristics of the cells, the residence time of the cell slurry in the centrifuge, and the settling depth. Settling depth can be kept small through the design of the centrifuge. The residence time of the slurry in the centrifuge can be controlled by controlling the flow rate. Heasman et al. (2000) evaluated the extent of cell recovery and the effects of cell viability at different conditions of centrifugation. Nine different strains of microalgae were assessed (Heasman et al., 2000). A cell harvest efficiency of $>95 \%$ was obtained only at $13,000 \times g$. The harvest efficiency declined to $60 \%$ at $6000 \times g$ and $40 \%$ at $1300 \times g$. Cell viability depended significantly on the algal species and the method of centrifugation (Heasman et al., 2000). Information on comparative performance of some centrifugal methods of recovering microalgal biomass is given in Table 1 (Mohn, 1980). Of the methods shown (Table 1), only hydrocyclone proved unsatisfactory for the application shown. The other methods were quite effective for biomass recovery (Table 1).

\subsection{Filtration}

Filter presses operating under pressure or vacuum are satisfactory for recovering relatively large microalgae such as Coelastrum proboscideum and Spirulina platensis but fail to recover organisms approaching bacterial dimensions (e.g., Scenedesmus, Dunaliella, Chlorella) (Mohn, 1980). Using a chamber filter press, a concentration factor of 245 could be attained for the large microalgae $C$. proboscideum to produce a cake with $27 \%$ solids (Mohn, 1980). Rotary drum vacuum or pressure filters can be used also. A rotary drum precoat filtration process has been described for recovering microalgal biomass (Gudin and Therpenier, 1986; Gudin and Chaumont, 1991). Diatomaceous earth or cellulose (i.e., filter aid) was first filtered through the filter cloth to form a cake or precoat of the filter aid. The biomass slurry was then filtered through the precoat layer. The settled biomass was recovered by scraping off together with a thin layer of the filter aid. Recovery by precoat filtration is not suitable if contamination of the biomass with filter aid cannot be tolerated. This would generally be the case if the biomass is intended for use as aquaculture feed, or further processing is required for extracting intracellular products from the biomass.

For the small cells of Dunaliella, filtration through sand filters, cellulose fibers and other filter materials has not proved practical (Ben-Amotz and Avron, 1987). One exception was filtration through diatomaceous earth. Dunaliella grown in salt ponds in Australia could be recovered by passing diluted culture broth through diatomaceous earth. The filtered alga was then directly extracted with organic solvent to recover $\beta$-carotene (Ruane, 1977).

Table 2 provides information on some pressure and vacuum filters that have been used to recover microalgae (Mohn, 1980). Of the filters listed in Table 2, the pressure belt filer and the vacuum filter thickener are not recommended for use with the microalgae tested.

Membrane microfiltration and ultrafiltration are possible alternatives to conventional filtration for recovering algal biomass. Microfiltration is suitable for fragile cells (Petrusevski et al., 1995), but large-scale processes for producing algal biomass do not generally use 
Table 2

Performance of some pressure and vacuum filters used in harvesting of microalgae (based on Mohn, 1980)

\begin{tabular}{|c|c|c|c|c|c|c|c|c|}
\hline Type & Machine and make & $\begin{array}{l}\text { Operational } \\
\text { mode }\end{array}$ & $\begin{array}{l}\text { Concentration } \\
\text { procedure }\end{array}$ & Alga & $\begin{array}{l}\text { Suspended } \\
\text { solids (\%) in } \\
\text { concentrate } \\
\text { (concentration } \\
\text { factor in } \\
\text { parentheses) }\end{array}$ & $\begin{array}{l}\text { Energy } \\
(\mathrm{kW} \mathrm{h}) \\
\text { consumed } \\
\text { per } \mathrm{m}^{3}\end{array}$ & $\begin{array}{l}\text { Relative } \\
\text { harvesting } \\
\cos ^{\mathrm{a}}\end{array}$ & Reliability \\
\hline \multirow[t]{5}{*}{$\begin{array}{l}\text { Pressure } \\
\text { filter }\end{array}$} & $\begin{array}{l}\text { Netzsch chamber } \\
\text { filter; Netzsch }\end{array}$ & Discontinuous & One step & C. proboscideum & $22-27(245)$ & 0.88 & 0.4 & Very high \\
\hline & Belt press; Bellmer & Continuous & $\begin{array}{l}\text { Needs preconcentration } \\
\text { to } \sim 4 \% \text { total } \\
\text { suspended solids, } \\
\text { or flocculation }\end{array}$ & C. proboscideum & $18(180)$ & 0.5 & 1.1 & - \\
\hline & Suction filter; Seitz & Discontinuous & $\begin{array}{l}\text { Original and } \\
\text { preconcentrated } \\
\text { suspension with } \\
1.5 \% \text { total } \\
\text { suspended solids }\end{array}$ & C. proboscideum & $16(160)$ & - & - & Good \\
\hline & $\begin{array}{l}\text { Cylindrical sieve } \\
\text { rotators; Engelsmann }\end{array}$ & Continuous & $\begin{array}{l}\text { One step and for } \\
\text { preconcentration }\end{array}$ & C. proboscideum & $7.5(75)$ & 0.3 & 1.9 & Sufficient \\
\hline & $\begin{array}{l}\text { Filter basket; } \\
\text { Seitz Dinglinger }\end{array}$ & Discontinuous & For preconcentration & C. proboscideum & $5(50)$ & 0.2 & 0.48 & Good \\
\hline \multirow[t]{5}{*}{$\begin{array}{l}\text { Vacuum } \\
\text { filter }\end{array}$} & $\begin{array}{l}\text { Non-precoat vacuum } \\
\text { drum filter; } \\
\text { Dorr Olliver }\end{array}$ & Continuous & One step & C. proboscideum & $18(180)$ & 5.9 & 3.9 & Low \\
\hline & $\begin{array}{l}\text { Potato starch } \\
\text { precoat vacuum } \\
\text { drum filter; Nivoba, } \\
\text { Walther }\end{array}$ & $\begin{array}{l}\text { Continuous } \\
\text { after precoating }\end{array}$ & $\begin{array}{l}\text { Needs } 2 \text { - to } 15 \text {-fold } \\
\text { preconcentration }\end{array}$ & $\begin{array}{l}\text { C. proboscideum, } \\
\text { Scenedesmus }\end{array}$ & $37(2-18.5)$ & - & - & Good \\
\hline & Suction filter & Discontinuous & One step & C. proboscideum & $8(80)$ & 0.1 & 4.5 & Satisfactory \\
\hline & Belt filter; Dinglinger & Continuous & For preconcentration & C. proboscideum & $9.5(95)$ & 0.45 & 0.88 & Good \\
\hline & $\begin{array}{l}\text { Filter thickener; } \\
\text { Schenck }\end{array}$ & Discontinuous & For preconcentration & $\begin{array}{l}\text { C. proboscideum, } \\
\text { Scenedesmus }\end{array}$ & $5-7(50-70)$ & 1.6 & 3.2 & Satisfactory \\
\hline
\end{tabular}

${ }^{a}$ Does not include labor. Relative harvesting costs are calculated on the basis of operational cost of a self-cleaning plate separator being 1.0. 
membrane filtration. Small aquaculture farms do frequently use membrane technology for recovering algal cells for feeding shellfish larvae (Borowitzka, 1997).

Rossignol et al. (1999) investigated the use of polymer membranes for continuous recovery of two marine microalgae (Haslea ostrearia and Skeletonema costatum). Eight commercial membranes were evaluated. A polyacrylonitrile ultrafiltration membrane of 40$\mathrm{kDa}$ molecular weight cutoff was found satisfactory for recovering the cells (Rossignol et al., 1999). These membranes could be used on a long-term basis under conditions of a low imposed transmembrane pressure and a relatively low cross-flow velocity (to keep shear rates low for the fragile cells). Although microfiltration membranes provided higher initial fluxes than the ultrafiltration membranes, the former tended to clog up more readily. Flux values of between 15 and $601 \mathrm{~m}^{-2} \mathrm{~h}^{-1}$ were attained with the ultrafilter membranes.

Membrane replacement and pumping are the major cost contributors to membrane filtration processes. Generally, microfiltration can be more cost-effective than centrifugation if only small volumes (e.g., $<2 \mathrm{~m}^{3}$ day ${ }^{-1}$ ) are to be filtered. For larger scale of production (e.g., $>20 \mathrm{~m}^{3}$ day $^{-1}$ ), centrifugation may be a more economic method of recovering the biomass (MacKay and Salusbury, 1988).

\section{Biomass processing for metabolite recovery}

\subsection{Dehydration of biomass}

Harvesting generally results in a 50- to 200-fold concentration of algal biomass. The harvested biomass slurry (5-15\% dry solids) must be processed rapidly, or it can spoil within a few hours in a hot climate. The specific postharvest processing necessary depends strongly on the desired product. Dehydration or drying of the biomass is commonly used to extend the shelf-life of the biomass especially if biomass is the final product. Drying methods that have been used for microalgae include spray drying, drum drying, freeze-drying and sun drying. Spray drying, freeze-drying and drum drying of $\beta$-carotene-rich Dunaliella all produce satisfactory results in terms of the uniformity of the biomass powder and stability of $\beta$ carotene in the biomass (Ben-Amotz and Avron, 1987).

Spray drying is the method of choice for high-value products $\left(>\$ 1000\right.$ ton $\left.^{-1}\right)$, but it can cause significant deterioration of some algal components such as pigments. The expense of drying can be a significant impediment to producing microalgal biomass powder for use in food and feeds. Freeze-drying, or lyophilization, has been widely used for drying microalgae in research laboratories; however, freeze-drying is too expensive for use in large-scale commercial recovery of microalgal products. In some cases, solvent extraction of dry biomass has proved much more effective for recovery of intracellular metabolites than the extraction of wet biomass.

Intracellular products such as oils can be difficult to solvent extract from wet biomass (Belarbi et al., 2000) of undisrupted cells, but are extracted readily if the biomass has been freeze-dried. Lipids have been extracted directly from freeze-dried biomass of Isochrysis galbana (Molina Grima et al., 1994). 


\subsection{Cell disruption}

Cell disruption is often necessary for recovering intracellular products from microalgae (Ruane, 1977; Mendes-Pinto et al., 2001). Most of the cell disruption methods developed for use with nonphotosynthetic microorganisms (Chisti and Moo-Young, 1986; Middelberg, 1994) can be applied to microalgae. High-pressure homogenisers are widely used to disrupt Haematococcus cells for use as fish feed. Disruption greatly enhances the bioavailability of and the assimilation of the pigments from the cells. Agitation of microalgal biomass in presence of glass and ceramic beads ( $\sim 0.5 \mathrm{~mm}$ bead diameter) in bead mills (Chisti and Moo-Young, 1986) has been used to disrupt cells (Hedenskog et al., 1969) of Scenedesmus obliquus, S. platensis and Monodus subterraneous. Ultrasonication of suspended microalgal cells can be used to disrupt small amounts of biomass (Dunstan et al., 1992; Bermejo Román et al., 2001) but this method is not applicable to large-scale use.

Different cell disruption processes have been assessed for recovering astaxanthin from encysted cells of Haematococcus pluvialis (Mendes-Pinto et al., 2001) (Fig. 4). Biomass that had been autoclaved or mechanically disrupted in a high pressure homogenizer, yielded three times as much astaxanthin as biomass treated with other methods (Fig. 4). The latter included treatment with acid, alkali, and enzymes. Bubrick (1991) used cryogenic $\left(-170{ }^{\circ} \mathrm{C}\right)$ grinding of dried Haematococcus biomass to extract astaxanthin with butylated hydroxytoluene. This method is not realistic for large-scale commercial use.

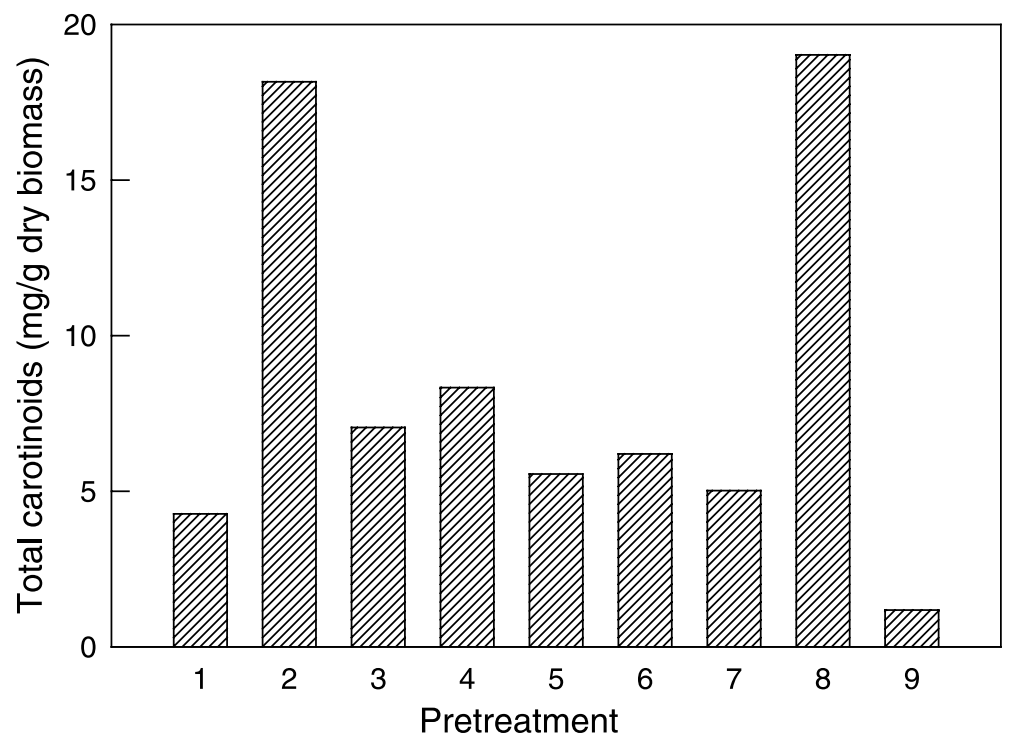

Fig. 4. Effect of various biomass pretreatments on recovery of carotinoids in acetone extracts of Haematococccus: 1. No pretreatment; 2. Autoclave; 3. Hydrochloric acid, $15 \mathrm{~min} ; 4$. Hydrochloric acid, $30 \mathrm{~min}$; 5 . Sodium hydroxide, $15 \mathrm{~min}$; 6. Sodium hydroxide, $30 \mathrm{~min}$; 7. Enzyme; 8. Mechanical disruption; 9. Spray drying (MendesPinto et al., 2001). 
While treatment with alkali is an effective method of lysing the cell wall, it is not generally suitable for sensitive products such as proteins. However, alkaline lysis can be used to isolate free fatty acids from microalgae. Free fatty acids of Porphyridium cruentum (Giménez Giménez et al., 1998) and Phaeodactylum tricornutum (Robles Medina et al., 1995; Cartens et al., 1996; Molina Grima et al., 1996; Ibáñez González et al., 1998) have been extracted by direct saponification of wet biomass with $\mathrm{KOH}-$ ethanol mixture.

\subsection{Extraction and purification of metabolites}

Solvent extraction of algal biomass is widely used to extract metabolites such as astaxanthin, $\beta$-carotene and essential fatty acids. Hexane, ethanol, chloroform and diethyl ether can extract fatty acids such as EPA, docosohexaenoic acid (DHA) and arachidonic acid (AA) from various microalgae. Fatty acid extraction from P. cruentum, P. tricornutum, I. galbana, M. subterraneous and other microalgae has been described (Robles Medina et al., 1995; Giménez Giménez et al., 1998; Belarbi et al., 2000). Extraction with aqueous buffers has been used to obtain phycobiliproteins from P. cruentum (Bermejo Román et al., 2001, 2002) and lutein from $C$. vulgaris (Li et al., 2001). Extraction of many proteins requires biomass that has not been dried previously (Bermejo Román et al., 2002).

Crude extracts are generally filtered and purified by various chromatographic methods to obtain the metabolite of interest. Supercritical fluid chromatography has been used to recover astaxanthin (Lim et al., 2002), polyunsaturated fatty acids and other compounds. Some other chromatographic methods that have been used for recovering pure fatty acids (or equivalent esters) have included reverse phase chromatography, silica gel adsorption chromatography and argentated silica gel chromatography (Robles Medina et al., 1995; Giménez Giménez et al., 1998; Belarbi et al., 2000). Proteins are usually purified using ion exchange chromatography (Bermejo Román et al., 2002).

\section{Process economics: a case study of EPA production}

Here, we discuss the economics of producing EPA from the marine microalga $P$. tricornutum, as a representative case study for producing high-value intracellular products from microalgae. The case study is useful in identifying potential bottlenecks to commercializing microalgae-derived products.

\subsection{The EPA production process}

The process for producing high-purity EPA from P. tricornutum is shown in Fig. 5. The process was developed at the University of Almería, Spain. All aspects of the process have been demonstrated at a pilot production scale. Modifications of the process have been also proved for recovering EPA from another microalga, M. subterraneus, and fish oil (Belarbi et al., 2000). The process consists of three distinct parts: (1) production and recovery of the microalgal biomass; (2) one-step extraction and esterification of oils in the wet biomass paste; 


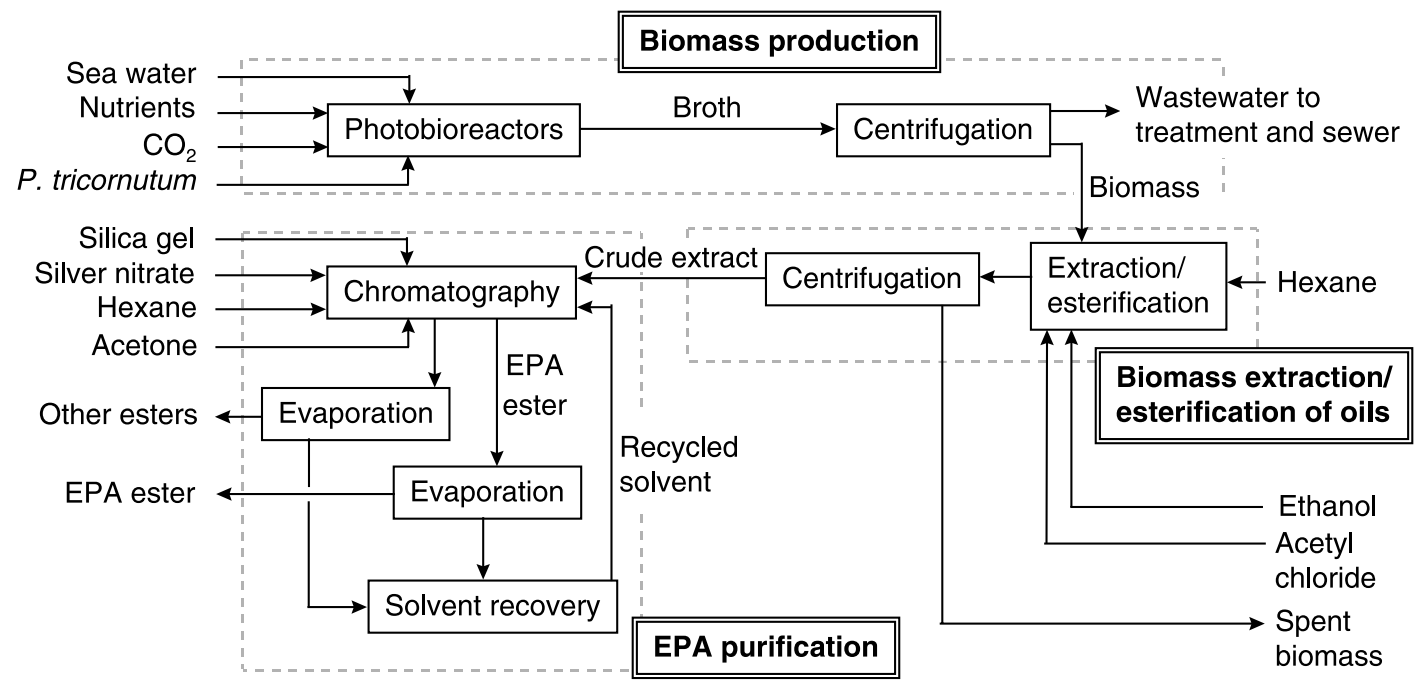

Fig. 5. Production of pure EPA from the microalga P. tricornutum.

and (3) chromatographic purification of the crude extract to yield highly pure ( $>96 \%$ pure) EPA ester and other fatty ester co-products (Fig. 5). The optimal processing conditions and the scale up of recovery have been described by Belarbi et al. (2000).

Outdoor-placed tubular photobioreactors are used to produce the alga in continuous culture (Fig. 6) (Acién Fernández et al., 1998, 2001; Molina Grima et al., 1999). Typically, the dilution rate used is one-third bioreactor volume per day during the daylight hours. The $P$. tricornutum biomass concentration in the broth from the photobioreactors is $3.8 \mathrm{~kg} \mathrm{~m}^{-3}$ on average. The broth is centrifuged in a continuous flow disc stack centrifuge to recover a biomass paste with $\sim 80 \%$ moisture content. The spent broth is treated and discharged to sewer. The biomass contains $\sim 2.5 \%(\mathrm{w} / \mathrm{w})$ EPA of which about $70 \%$ is recoverable. There is $\sim 10 \%$ total oil in the dry biomass. The recovered biomass paste is processed through a onestep extraction-esterification operation that yields a crude extract of the fatty esters. This onestep process eliminates several intermediate processing steps that would be required if extraction and esterification of the oil are carried out in separate steps (Rodríguez-Ruiz et al., 1998). Esterification-extraction requires hexane, ethanol (for obtaining ethyl esters) and acetyl chloride (Fig. 5). Although, P. tricornutum biomass is a potentially suitable animal feed, the solvent extracted alga that has been depleted of its fat contents and contains residual solvents can be reasonably disposed off only by landfilling or incineration.

The biomass-free esterified crude extract is purified by silver silica gel chromatography to obtain a highly pure ( $>96 \%$ pure) EPA ester and esters of the other fatty acids present in the alga. The solvents used in chromatography (i.e., hexane and acetone) are recovered by evaporation of the eluted fractions. The solvents are recycled. Possible alternatives or adjuncts to using silver silica gel chromatography include membrane-based selective enrichment of EPA, supercritical chromatography, kinetic resolution, and winterization. Processes such as urea complexation and preparative HPLC are of limited value in the commercial purification of EPA. 


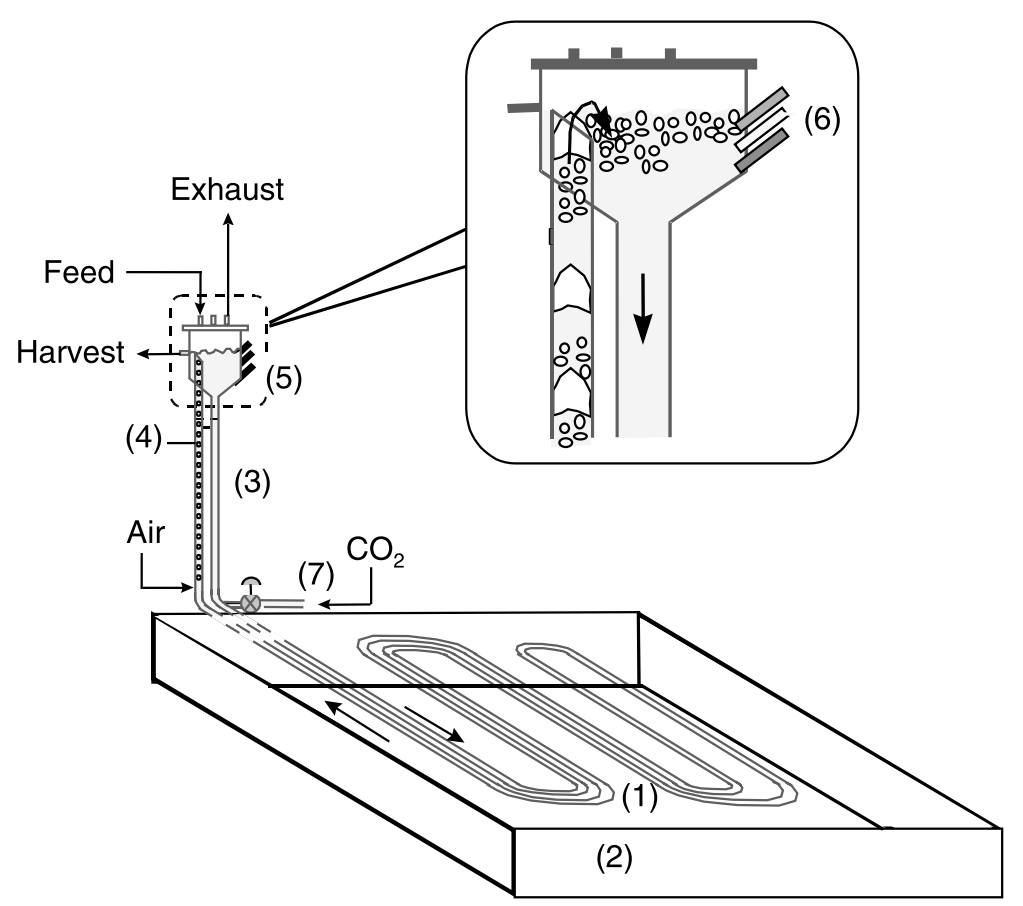

Fig. 6. A tubular photobioreactor used for culturing the alga. The tubular solar receiver (1) is held in a thermostated pool (2) for temperature control. The airlift device (3) is used to circulate the culture broth through the solar loop. Only the riser zone (4) of the airlift device is injected with air. The injected gas separates from the culture broth in the degassing zone (5) before the broth returns to the solar loop. The degasser zone contains sensors (6) for $\mathrm{pH}$, dissolved oxygen and temperature. The carbon dioxide required for photosynthesis is injected at the entrance (7) of the solar loop (Acién Fernández et al., 1998, 2001).

\subsection{Process economics}

\subsubsection{Basis}

The basis of the economic analysis was a facility producing $430 \mathrm{~kg}$ of $96 \%$ pure EPA per annum. The biomass and the crude extract required for the EPA were produced within the integrated facility. Producing $430 \mathrm{~kg}$ of EPA required a biomass production capacity of 26.2 tons (dry basis) per annum and this translated to $2620 \mathrm{~kg}$ of crude esterified extract. The integrated production facility was costed for a coastal "green field" site in the south of Spain. This provided ready access to sea water and the irradiance levels required to attain an average biomass productivity of $\sim 1.25 \mathrm{~kg} \mathrm{~m}^{-3}$ day ${ }^{-1}$ in continuous culture.

The processes for producing the biomass, the crude esterified extract, and the pure EPA from the extract, were evaluated separately to gain a detailed insight into the major contributors to the final price of producing the EPA. This approach allowed us to separately estimate the cost of the biomass paste, the crude esterified extract and the EPA purified from the crude extract. For the economic evaluation, the components of costs taken into account included the charges related to capital investment and all operating expenses. The investment 
Table 3

Major equipment list and costs for algal biomass production

\begin{tabular}{|c|c|c|c|c|}
\hline Item & $\begin{array}{l}\text { Delivered } \\
\text { cost }(\$)\end{array}$ & $\begin{array}{l}\text { No. } \\
\text { of units }\end{array}$ & $\begin{array}{l}\text { Total } \\
\text { cost }\end{array}$ & $\begin{array}{l}\% \text { of } \\
\text { MEC }\end{array}$ \\
\hline 1. Photobioreactors $\left(0.8 \mathrm{~m}^{3}\right)$ & 3524 & 75 & 264,300 & 30.0 \\
\hline 2. Centrifuge ( 24 bowl, solids discharge, s.s., $2.99 \mathrm{~m}^{3} / \mathrm{h}$ ) & 123,949 & 2 & 247,898 & 28.1 \\
\hline 3. Medium filter unit $\left(5.99 \mathrm{~m}^{3} / \mathrm{h}\right)$ & 18,014 & 1 & 18,014 & 2.0 \\
\hline 4. Medium feed pumps $\left(0.04 \mathrm{~m}^{3} / \mathrm{h}\right)$ & 349 & 75 & 26,175 & 3.0 \\
\hline 5. Medium preparation tank $\left(19.96 \mathrm{~m}^{3}\right)$ & 34,814 & 3 & 104,442 & 11.9 \\
\hline 6. Harvest broth storage tank $\left(19.96 \mathrm{~m}^{3}\right)$ & 34,814 & 3 & 104,442 & 11.9 \\
\hline 7. Centrifuge feed pumps $\left(2.99 \mathrm{~m}^{3} / \mathrm{h}\right)$ & 841 & 2 & 1682 & 0.2 \\
\hline 8. Air compressors $\left(240 \mathrm{~m}^{3} / \mathrm{h}\right)$ & 26,103 & 3 & 78,309 & 8.9 \\
\hline 9. Harvest biomass conveyer belts & 7100 & 2 & 14,200 & 1.6 \\
\hline 10. Seawater pump station $\left(5.99 \mathrm{~m}^{3} / \mathrm{h}\right)$ & 13,661 & 1 & 13,661 & 1.6 \\
\hline 11. Carbon dioxide supply station $(27.4 \mathrm{~kg} / \mathrm{h})$ & 3006 & 1 & 3006 & 0.3 \\
\hline 12. Weighing station & 2366 & 1 & 2366 & 0.3 \\
\hline 13. Biomass silos $\left(0.07 \mathrm{~m}^{3}\right)$ & 1370 & 2 & 2740 & 0.3 \\
\hline Total MEC (\$) & & & 881,235 & \\
\hline
\end{tabular}

Table 4

Total and annual fixed capital for biomass production

\begin{tabular}{|c|c|c|}
\hline Item & Cost $(\$)$ & $\%$ of $A$ \\
\hline 1. Major purchased equipment (MEC) & 881,235 & 29.2 \\
\hline 2. Installation costs (at $0.3 \mathrm{MEC}$ ) & 264,371 & 8.8 \\
\hline 3. Instrumentation and control (at 0.1 MEC) & 88,124 & 2.9 \\
\hline 4. Piping (at $0.3 \mathrm{MEC}$ ) & 264,371 & 8.8 \\
\hline 5. Electrical (at $0.1 \mathrm{MEC}$ ) & 88,124 & 2.9 \\
\hline 6. Buildings (at $0.3 \mathrm{MEC}$ ) & 264,371 & 8.8 \\
\hline 7. Yard improvements (at $0.1 \mathrm{MEC}$ ) & 88,124 & 2.9 \\
\hline 8. Service facilities (at $0.2 \mathrm{MEC}$ ) & 176,247 & 5.8 \\
\hline 9. Land (at $0.06 \mathrm{MEC}$ ) & 52,874 & 1.8 \\
\hline 10. Engineering and supervision (at $0.25 \mathrm{MEC}$ ) & 220,309 & 7.3 \\
\hline 11. Construction expenses (at $0.1 \sum$ items $1-9$ ) & 216,784 & 7.2 \\
\hline 12. Contractor's fee (at $0.05 \sum$ items $1-9$ ) & 108,392 & 3.6 \\
\hline 13. Contingency (at 0.06 total fixed capital investment) & 180,888 & 6.0 \\
\hline Total fixed capital investment, $A(\$)$ & $3,014,803$ & 96.0 \\
\hline Item & Cost $(\$)$ & $\%$ of $B$ \\
\hline Depreciation (at ( $\sum$ items $\left.1-8,10-13\right) / 10$ years) & 284,134 & 85.6 \\
\hline Property tax (at 0.01 depreciation) & 2841 & 0.9 \\
\hline Insurance (at 0.006 depreciation) & 1705 & 0.5 \\
\hline Debt service (none, $100 \%$ equity capital) & 0 & 0.0 \\
\hline Purchase tax ((at 0.16 of items $1-12) / 10)$ & 43,413 & 13.1 \\
\hline Total fixed capital per year, $B(\$)$ & 332,093 & \\
\hline
\end{tabular}


Table 5

Direct costs of biomass production

\begin{tabular}{llrr}
\hline Raw materials & Total quantity $(\mathrm{kg})$ & Cost $(\$)$ & \% of $C$ \\
\hline 1. Culture medium (at $\$ 0.5883 / \mathrm{kg})$ & 65,500 & 38,534 & 34.9 \\
2. Carbon dioxide (at $\$ 0.4706 / \mathrm{kg})$ & 96,940 & 45,620 & 41.3 \\
3. Media filters (at $\$ 70.59 / \mathrm{unit})$ & 210 units & 14,824 & 13.4 \\
4 . Air filters (at $\$ 94.12 /$ unit) & 105 units & 9883 & 9.0 \\
5. Other consumables (at $\$ 117.65 / \mathrm{kg})$ & 13 & 1529 & 1.4 \\
Total raw materials cost, $C$ (\$) & & $\mathbf{1 1 0 , 3 9 0}$ &
\end{tabular}

Utilities

$\begin{array}{lrc}\text { Total quantity } & \text { Cost (\$) } & \text { \% of D } \\ 408,196 & 0 & 0 \\ 99,822 \mathrm{~kW} \mathrm{~h} & 5873 & 100 \\ & \mathbf{5 8 7 3} & \end{array}$

6. Cooling water (included in pumping station)

7. Power (at $\$ 0.05883 / \mathrm{kW} \mathrm{h}$ )

Total, $D$ (\$)

\begin{tabular}{lrr} 
Total quantity & Cost $(\$)$ & \% of $E$ \\
\hline 3 persons & 140,160 & 35.6 \\
& 28,032 & 7.1 \\
& 42,048 & 10.7 \\
& 35,249 & 8.9 \\
& 442 & 0.1 \\
& 111,893 & 28.4 \\
& & \\
& 24,312 & 6.2 \\
$10,480 \mathrm{~m}^{3}$ & 5813 & 1.5 \\
& 0 & 0.0 \\
& 6183 & 1.6 \\
& $\mathbf{3 9 4 , 1 3 3}$ & \\
& $\mathbf{8 4 2 , 4 8 8}$ & \\
& $\mathbf{3 2 . 1 6}$ & \\
& &
\end{tabular}

Total production cost, $F(B$ (Table 4$)+$
Unit cost of producing biomass $(\$ / \mathbf{k g})$

E) (\$)

Table 6

Major equipment list and costs for production of crude esterified algal oil

\begin{tabular}{lclrr}
\hline Item & $\begin{array}{l}\text { Delivered } \\
\text { cost }(\$)\end{array}$ & $\begin{array}{l}\text { No. } \\
\text { of units }\end{array}$ & $\begin{array}{r}\text { Total } \\
\text { cost }\end{array}$ & $\begin{array}{r}\text { \% of } \\
\text { MEC }\end{array}$ \\
\hline 1. Ethanol tank $\left(1.5 \mathrm{~m}^{3}\right.$, carbon steel) & 2404 & 1 & 2404 & 4.6 \\
2. Acetyl chloride tank $\left(1 \mathrm{~m}^{3}\right.$, carbon steel) & 1881 & 1 & 1881 & 3.6 \\
3. Reactor $\left(2 \mathrm{~m}^{3}, 66 \mathrm{psig}\right.$, jacketed) & 5242 & 1 & 5242 & 10.0 \\
4. Hexane storage tanks $\left(60 \mathrm{~m}^{3}\right)$ & 11,613 & 2 & 23,226 & 44.3 \\
5. Holding tank $\left(2.5 \mathrm{~m}^{3}\right.$, carbon steel $)$ & 3434 & 1 & 3434 & 6.5 \\
6. Evaporator $\left(50 \mathrm{ft}^{2}\right)$ & 14,622 & 1 & 14,622 & 27.9 \\
7. Condenser $\left(\right.$ shell and tube, $\left.5 \mathrm{~m}^{2}\right)$ & 1678 & 1 & 1678 & 3.2 \\
Total MEC (\$) & & & $\mathbf{5 2 , 4 8 7}$ & \\
\hline
\end{tabular}


Table 7

Total and annual fixed capital for production of crude esterified algal oil

\begin{tabular}{lrr}
\hline Item & Cost $(\$)$ & $\%$ of $A$ \\
\hline 1. Major purchased equipment (MEC) & 52,487 & 24.9 \\
2. Installation costs (at 0.4 MEC) & 20,995 & 10.0 \\
3. Instrumentation and control (at 0.15 MEC) & 7873 & 3.7 \\
4. Piping (at 0.4 MEC) & 20,995 & 10.0 \\
5. Electrical (at 0.1 MEC) & 5249 & 2.5 \\
6. Buildings (at 0.45 MEC) & 23,619 & 11.2 \\
7. Yard improvements (at 0.12 MEC) & 6298 & 3.0 \\
8. Service facilities (at 0.2 MEC) & 10,497 & 5.0 \\
9. Land (at 0.06 MEC) & 3149 & 1.5 \\
10. Engineering and supervision (at 0.3 MEC) & 15,746 & 7.5 \\
11. Construction expenses (at 0.1 $\sum$ items 1-9) & 15,116 & 7.2 \\
12. Contractor's fee (at $0.05 \sum$ items 1-9) & 7558 & 3.6 \\
13. Contingency (at 0.08 total fixed capital investment) & 16,852 & 8.0 \\
Total fixed capital investment, $A$ (\$) & $\mathbf{2 1 0 , 6 4 8}$ & 98.0 \\
& & \\
Item & Cost $(\$)$ & $\%$ of $B$ \\
\hline Depreciation (at $\left(\sum\right.$ items $\left.1-8,10-13\right) / 10$ years) & 20,329 & 85.8 \\
Property tax (at 0.01 depreciation) & 203 & 0.9 \\
Insurance (at 0.006 depreciation) & 122 & 0.5 \\
Debt service (none, $100 \%$ equity capital) & 0 & 0.0 \\
Purchase tax ((at 0.16 of items 1-12)/10) & 3033 & 12.8 \\
Total fixed capital per year, $B$ (\$) & $\mathbf{2 3 , 6 8 7}$ & \\
\hline
\end{tabular}

capital was assumed to be $100 \%$ venture capital and, therefore, no debt charges were included. All prices were for the year 2001.

\subsubsection{Biomass production}

Producing the specified 26.2 tons of $P$. tricornutum biomass annually requires an array of 75 tubular photobioreactors each having a volume of $0.8 \mathrm{~m}^{3}$. The cost of photobioreactors is based on local experience. The biomass is harvested using a continuous flow disk stack centrifuge. The major process equipment required for such a facility and the delivered cost of the equipment are listed in Table 3. The costing of the photobioreactors and the seawater pumping station is based on direct experience. Other costs have been estimated using standard process engineering data (Humphreys, 1991; Peters and Timmerhaus, 1991) or actual quotes from vendors. The fixed capital investment required for the biomass paste production facility is itemized in Table 4. In keeping with standard bioprocess engineering practice (Humphreys, 1991; Peters and Timmerhaus, 1991), the fixed costs are generally estimated as factors of the major equipment costs (MEC). The fixed investment, depreciated over 10 years, contributes $\sim 39 \%$ to the cost of producing the biomass. The remaining $61 \%$ of the production cost originates in the direct production expenses itemized in Table 5. The direct production costs account for the raw materials consumed, utilities charges, labor, general overheads, and waste treatment. Marketing expenses are not included, as the biomass 
Table 8

Direct production costs of crude esterified algal oil

\begin{tabular}{lccc}
\hline Raw materials & Total quantity & Cost $(\$)$ & \% of $C$ \\
\hline 1. Algal biomass, $\mathrm{kg}($ at $\$ 32.16 / \mathrm{kg})$ & 26,200 & 842,592 & 95.0 \\
2. Ethanol, $\mathrm{m}^{3}$ (at $\left.\$ 784.70 / \mathrm{m}^{3}\right)$ & 33 & 25,895 & 2.9 \\
3. Acetyl chloride, $\mathrm{m}^{3}\left(\right.$ at $\left.\$ 1533 / \mathrm{m}^{3}\right)$ & 7 & 10,731 & 1.2 \\
4. Hexane, $\mathrm{m}^{3}$ (at $\left.\$ 364.7 / \mathrm{m}^{3}\right)$ & 20 & 7294 & 0.8 \\
Total raw materials cost, $C(\mathbf{(})$ & & $\mathbf{8 8 6 , 5 1 2}$ &
\end{tabular}

Utilities

\begin{tabular}{ccc} 
Total quantity & Cost $(\$)$ & $\%$ of $D$ \\
\hline 5790 & 170.226 & 43.2 \\
39,300 & 192.57 & 48.9 \\
524 & 31 & 7.8 \\
& $\mathbf{3 9 4}$ &
\end{tabular}

\begin{tabular}{|c|c|c|c|}
\hline Others & Total quantity & Cost $(\$)$ & $\%$ of $E$ \\
\hline 8. Labor (at $\$ 16 / \mathrm{h}, 1$ shift) & 1 person & 46,720 & 36.4 \\
\hline 9. Supervision (at 0.2 labor) & & 9344 & 7.3 \\
\hline 10. Payroll charges (at 0.25 (labor + supervision)) & & 14,016 & 10.9 \\
\hline 11. Maintenance (at $0.04 \mathrm{MEC}$ ) & & 2099 & 1.6 \\
\hline 12. Operating supplies (at $0.004 \mathrm{C}$ ) & & 3546 & 2.8 \\
\hline $\begin{array}{l}\text { 13. General plant overheads (at } 0.55 \\
(\text { labor }+ \text { supervision }+ \text { maintenance) })\end{array}$ & & 31,990 & 24.9 \\
\hline 14. Tax (at $0.16 \sum$ items $2-7,11$ and 12 ) & & 7993 & 6.2 \\
\hline 15. Contingency (at $0.1 \sum$ items $2-7$ ) & & 4431 & 3.5 \\
\hline 16. Marketing (not included) & & 0 & 0.0 \\
\hline 17. Spent biomass $(\mathrm{kg})$ disposal (at $\$ 350 /$ ton) & 23,318 & 8161 & 6.4 \\
\hline Total, $E \mathbf{( \$ )}$ & & 128,302 & \\
\hline Total production cost, $F(B$ (Table 7) $+C+D+E)(\$)$ & & $1,038,894$ & \\
\hline Unit cost of producing esterified oil $(\$ / \mathbf{k g})$ & & 396.52 & \\
\hline
\end{tabular}

produced is "sold" internally to the extraction-esterification part of the overall integrated process.

The cost of producing the biomass is estimated at $\$ 32.16 / \mathrm{kg}$ (dry basis) (Table 5). This value is derived by summing $B$ (Table 4), $C, D$ and $E$ (Table 5) and dividing the result by 26.2 tons, the total annual biomass production. Raw materials (excluding utilities) and direct process labor contribute $\sim 13 \%$ and $\sim 17 \%$, respectively, to the production cost. The labor input and raw materials consumption cannot be reduced significantly. Depreciation charges contribute $\sim 34 \%$ to annual production cost, but the present technology does not permit a significant reduction in capital expenses. One significant option for reducing cost is through enhancing biomass productivity by engineered design of photobioreactors. A 30\% enhancement in productivity can reduce the cost of producing the biomass by $\sim 20 \%$. If the alga can be selected, engineered or otherwise coaxed into increasing the EPA content in the biomass, the production economics can be improved substantially. 
Table 9

Major equipment list and costs for producing purified EPA

\begin{tabular}{|c|c|c|c|c|}
\hline Item & $\begin{array}{l}\text { Delivered } \\
\text { cost }(\$)\end{array}$ & $\begin{array}{l}\text { No. } \\
\text { of units }\end{array}$ & $\begin{array}{l}\text { Total } \\
\text { cost }\end{array}$ & $\begin{array}{l}\% \text { of } \\
\text { MEC }\end{array}$ \\
\hline 1. Ethanol tank $\left(1.5 \mathrm{~m}^{3}\right.$, carbon steel $)$ & 2404 & 1 & 2404 & 0.5 \\
\hline 2. Acetyl chloride tank $\left(1 \mathrm{~m}^{3}\right.$, carbon steel $)$ & 1881 & 1 & 1881 & 0.4 \\
\hline 3. Reactor $\left(2 \mathrm{~m}^{3}, 66 \mathrm{psig}\right.$, jacketed $)$ & 5242 & 1 & 5242 & 1.0 \\
\hline 4. Hexane storage tanks $\left(60 \mathrm{~m}^{3}\right)$ & 11,613 & 2 & 23,226 & 4.6 \\
\hline 5. Holding tank $\left(2.5 \mathrm{~m}^{3}\right.$, carbon steel $)$ & 3434 & 1 & 3434 & 0.7 \\
\hline 6. Acetone storage $\left(4 \mathrm{~m}^{3}\right.$, carbon steel $)$ & 5016 & 1 & 5016 & 1.0 \\
\hline 7. Chromatography system (stainless steel 304) & 260,247 & 1 & 260,247 & 51.1 \\
\hline 8. Slurry tank with mixer $\left(1.5 \mathrm{~m}^{3}\right.$, carbon steel $)$ & 4447 & 1 & 4447 & 0.9 \\
\hline 9. Silica gel/ethanol slurry tank with mixer $\left(1 \mathrm{~m}^{3}\right.$, carbon steel $)$ & 2846 & 1 & 2846 & 0.6 \\
\hline 10. Activated slica gel storage silo $\left(2.5 \mathrm{~m}^{3}\right.$, carbon steel $)$ & 3638 & 1 & 3638 & 0.7 \\
\hline 11. Evaporator $\left(150 \mathrm{ft}^{2}\right)$ & 33,331 & 1 & 33,331 & 6.5 \\
\hline 12. Evaporator $\left(1000 \mathrm{ft}^{2}\right)$ & 131,762 & 1 & 131,762 & 25.9 \\
\hline 13. Condenser (shell and tube, $50 \mathrm{~m}^{2}$ ) & 9435 & 1 & 9435 & 1.9 \\
\hline 14. Condenser (shell and tube, $10 \mathrm{~m}^{2}$ ) & 2989 & 1 & 2989 & 0.6 \\
\hline 15. Dryer $(100 \mathrm{Ib} / \mathrm{h})$ & 19,808 & 1 & 19,808 & 3.9 \\
\hline Total MEC (\$) & & & 509,706 & \\
\hline
\end{tabular}

Table 10

Total and annual fixed capital for producing purified EPA

\begin{tabular}{lrr}
\hline Item & Cost $(\$)$ & $\%$ of $A$ \\
\hline 1. Major purchased equipment (MEC) & 509,706 & 24.9 \\
2. Installation costs (at 0.4 MEC) & 203,882 & 10.0 \\
3. Instrumentation and control (at 0.15 MEC) & 76,456 & 3.7 \\
4. Piping (at 0.4 MEC) & 203,882 & 10.0 \\
5. Electrical (at 0.1 MEC) & 50,971 & 2.5 \\
6. Buildings (at 0.45 MEC) & 229,368 & 11.2 \\
7. Yard improvements (at 0.12 MEC) & 61,165 & 3.0 \\
8. Service facilities (at 0.2 MEC) & 101,941 & 5.0 \\
9. Land (at 0.06 MEC) & 30,582 & 1.5 \\
10. Engineering and supervision (at 0.3 MEC) & 152,912 & 7.5 \\
11. Construction expenses (at 0.1 $\sum$ items 1-9) & 146,795 & 7.2 \\
12. Contractor's fee (at 0.05 $\sum$ items 1-9) & 73,398 & 3.6 \\
13. Contingency (at 0.08 total fixed capital investment) & 163,650 \\
Total fixed capital investment, $A$ (\$) & $\mathbf{2 , 0 4 5 , 6 2 0}$ & 8.0 \\
Item & & 0.0 \\
\hline Depreciation (at ( $\sum$ items 1-8, 10-13)/10 years) & Cost (\$) \\
Property tax (at 0.01 depreciation) & 197,413 \\
Insurance (at 0.006 depreciation) & 1974 \\
Debt service (none, 100\% equity capital) & 1184 \\
Purchase tax ((at 0.16 of $\sum$ items 1-12)/10) & 0.9 \\
Total fixed capital per year, $B$ (\$) & 29,457 & 0.5 \\
\hline
\end{tabular}




\subsubsection{Production of esterified crude oil extract}

Recovering $430 \mathrm{~kg} /$ annum pure EPA requires $2620 \mathrm{~kg}$ of esterified algal oil. The major equipment required for the one-step esterification-extraction facility and the delivered cost of the equipment are shown in Table 6 . The total annual fixed capital charges are calculated in Table 7 , as $\$ 23,687$. The capital charges contribute $<2.5 \%$ to the cost of the final crude extract. The latter is obtained by summing $B$ (Table 7), $C, D$ and $E$ (Table 8) and dividing the result by $2620 \mathrm{~kg}$ of crude oil produced. All the direct production costs are identified in Table 8. Of the direct costs, raw materials (excluding utilities) contribute $>85 \%$ of the cost of the crude extract oil. Much of this cost, i.e. $\sim 81 \%$ of the final cost of crude oil, is contributed by the microalgal biomass. Direct operating labor contributes only $\sim 4.5 \%$ to the final cost of the crude oil. Landfill disposal of spent biomass costs $\$ 350 /$ ton, or $<1 \%$ of the final oil cost.

\subsubsection{EPA recovery from mixed esters}

Argentated silica gel chromatography is used to recover pure EPA ( $>96 \%$ pure) from the crude oil. The relevant major process equipment needed and the costs are shown in Table 9.

Table 11

Direct costs of producing purified EPA

\begin{tabular}{|c|c|c|c|}
\hline Raw materials & Total quantity & Cost $(\$)$ & $\%$ of $C$ \\
\hline 1. Crude algal oil, $\mathrm{kg}$ (at $\$ 396.52 / \mathrm{kg}$ ) & 2620 & $1,038,882$ & 89.4 \\
\hline 2. Silica gel, $\mathrm{kg}$ (at $\$ 6.6 / \mathrm{kg}$ ) & 1100 & 7260 & 0.6 \\
\hline 3. Silver nitrate, $\mathrm{kg}$ (at $\$ 529.4 / \mathrm{kg}$ ) & 100 & 52,940 & 4.6 \\
\hline 4. Acetone, $\mathrm{m}^{3}$ (at $\left.\$ 419.4 / \mathrm{m}^{3}\right)$ & 20 & 8388 & 0.7 \\
\hline 5. Hexane, $\mathrm{m}^{3}$ (at $\$ 364.7 / \mathrm{m}^{3}$ ) & 150 & 54,705 & 4.7 \\
\hline Total raw materials cost, $C(\$)$ & & $1,162,175$ & \\
\hline Utilities & Total quantity & Cost $(\$)$ & $\%$ of $D$ \\
\hline 6. Cooling water, $\mathrm{m}^{3}\left(\$ 0.0294 / \mathrm{m}^{3}\right)$ & 69,600 & 2046 & 34.3 \\
\hline 7. Steam, $\mathrm{kg}$ (at $\$ 0.0049 / \mathrm{kg})$ & 670,421 & 3285 & 55.0 \\
\hline 8. Power, $\mathrm{kW} \mathrm{h}$ (at $\$ 0.05883 / \mathrm{kW} \mathrm{h}$ ) & 10,897 & 641 & 10.7 \\
\hline Total, $D(\$)$ & & 5972 & \\
\hline Others & Total quantity & Cost $(\$)$ & $\%$ of $E$ \\
\hline 9. Labor (at $\$ 16 / \mathrm{h}, 1$ shift) & 2 persons & 93,440 & 16.1 \\
\hline 10. Supervision (at 0.2 labor) & & 18,688 & 3.2 \\
\hline 11. Payroll charges (at 0.25 (labor + supervision)) & & 28,032 & 4.8 \\
\hline 12. Maintenance (at $0.04 \mathrm{MEC}$ ) & & 20,388 & 3.5 \\
\hline 13. Operating supplies (at $0.004 C$ ) & & 4649 & 0.8 \\
\hline 14. General plant overheads (at 0.55 (labor + supervision + maintenance) $)$ & & 72,884 & 12.6 \\
\hline 15. Tax (at $0.16 \sum$ items $2-8,12$ and 13 ) & & 24,688 & 4.3 \\
\hline 16. Contingency (at $0.1 \sum$ items $2-8$ ) & & 12,927 & 2.2 \\
\hline 17. Marketing (at $0.02 \sum$ items $1-15$ ) & & 304,912 & 52.5 \\
\hline Total, $E \mathbf{( \$ )}$ & & $\mathbf{5 8 0 , 6 0 7}$ & \\
\hline Total production cost, $F(B$ (Table 10) $+C+D+E)(\$)$ & & $1,978,783$ & \\
\hline Unit cost of producing esterified oil $(\$ / \mathrm{kg})$ & & 4602 & \\
\hline
\end{tabular}


The annual fixed capital charges are calculated in Table 10. The direct production expenses are itemized in Table 11. At a cost of production of $\$ 396.52 / \mathrm{kg}$, the crude oil accounts for $\sim 53 \%$ of the cost of producing the pure EPA ester. All raw materials, excluding utilities, but including crude oil, contribute $\sim 59 \%$ to the final EPA cost. The annual fixed capital charge contributes only $\sim 12 \%$ to the final cost. The contribution of the direct operating labor is relatively small, at $\sim 5 \%$ of final EPA cost. The latter works out to $\$ 4602 / \mathrm{kg}$ (Table 11), i.e. the sum of $B$ (Table 10), $C, D$ and $E$ (Table 11 ) divided by the $430-\mathrm{kg}$ production.

Cost of the biomass, the extraction-esterification of crude microalgal oil, and final purification contribute $43 \%, 53 \%$, and $4 \%$, respectively, to the cost of producing the final EPA product. Overall, the downstream parts of the process (i.e., the two processes downstream of paste biomass production) contribute $57 \%$ to production cost of the final product. Typically, the downstream recovery of microbial products accounts for $70-80 \%$ of the total cost of production (Chisti, 1998). This suggests that the microalgal biomass for producing EPA is significantly more expensive than the norms for bioprocesses. Clearly, monoseptic culture of microalgae in outdoor photobioreactors is expensive compared to heterotrophic growth of most commercial bacteria, yeast and fungi.

Processes for producing the biomass, crude algal oil, and purified EPA are compared in Fig. 7 to see how differently some of the major factors contribute to the costs of the final products of these processes. In comparison with biomass production, the raw materials costs for producing the crude oil and pure EPA are high (Fig. 7). These two latter processes require biomass and crude oil, respectively, and these raw materials are the overwhelming contributors to final production costs. At current market prices of high-purity EPA sourced from fish oil, microalgal sourced EPA is expensive even if we allow a significant credit for the byproducts. The cost of production of microalgal EPA needs to be reduced by at least $80 \%$ for the product to be

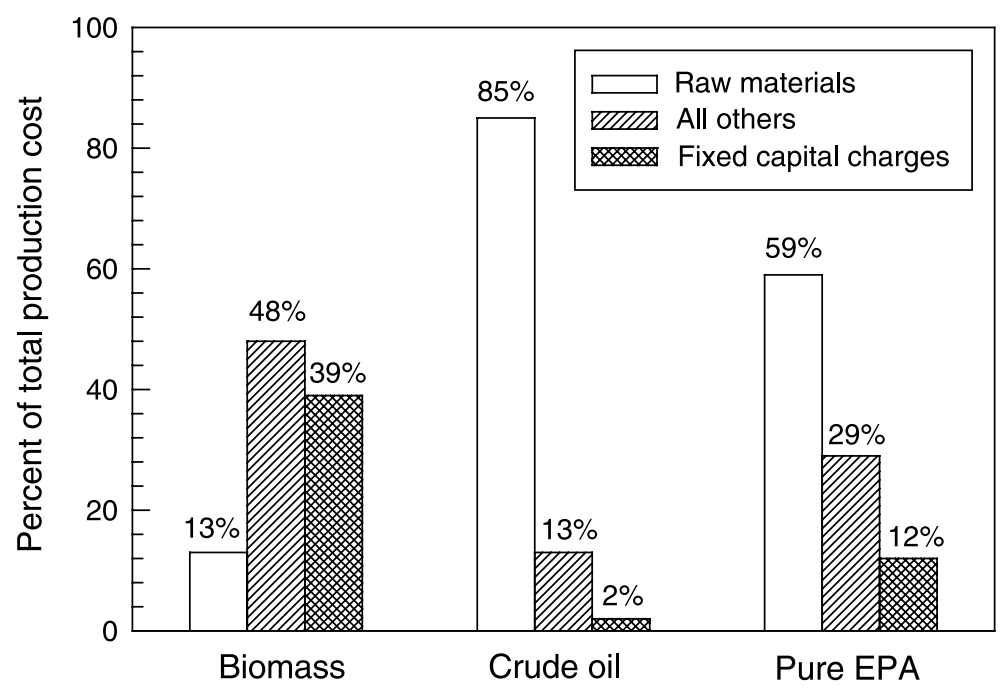

Fig. 7. Comparison of the major cost contributions to the cost of production of biomass, crude microalgal oil, and purified EPA. 
competitive. Attaining this level of process improvement is difficult but not insurmountable. Enhanced EPA content in the alga in combination with better performing photobioreactors, can potentially lead to economically feasible processes for microalgal sourced EPA.

\section{Conclusion}

Several options exist for recovering and processing microalgal biomass to obtain intracellular metabolites produced by microalgae. For commercial recovery of high-value products, centrifugation appears to be the preferred method of recovering the biomass from the broth. Centrifugation may be preceded by a flocculation step to improve recovery. When centrifugal recovery is not feasible, for example when the alga being recovered is fragile, microfiltration can be a suitable alternative. To the extent possible, it is preferable to use moist biomass paste in the metabolite recovery scheme because a prior drying step significantly adds to costs. A concentrated slurry of algal biomass may in some cases require a cell disruption pretreatment for extracting intracellular metabolites. Cell disruption by bead milling is a generally suitable method for most microalgae. High-value, high-purity products almost always require some kind of chromatography for recovery from crude extracts. The economics of metabolite production are influenced significantly by the cost of producing the biomass, the metabolite content in the biomass, and the cost of purification. For a product such as EPA, $60 \%$ of the costs arise from the recovery process. The biomass contributes $\sim 40 \%$ to the cost of EPA.

\section{References}

Acién Fernández FG, García F, Sánchez JA, Fernández JM, Molina E. Modelling of biomass productivity in tubular photobioreactors for microalgal cultures: effects of dilution rate, tube diameter and solar irradiance. Biotechnol Bioeng 1998;58:605-16.

Acién Fernández FG, Fernández Sevilla JM, Sánchez Pérez JA, Molina Grima E, Chisti Y. Airlift-driven external-loop tubular photobioreactors for outdoor production of microalgae: assessment of design and performance. Chem Eng Sci 2001;56: $2721-32$.

Banerjee A, Sharma R, Chisti Y, Banerjee UC. Botryococcus braunii: a renewable source of hydrocarbons and other chemicals. Crit Rev Biotechnol 2002;22:245-79.

Belarbi H, Molina E, Chisti Y. A process for high and scaleable recovery of high purity eicosapentaenoic acid esters from microalgae and fish oil. Enzyme Microb Technol 2000;26:516-29.

Belter PA, Cussler EL, Hu WS. Bioseparations: Downstream Processing for Biotechnology. New York: Wiley; 1988.

Ben-Amotz A, Avron M. The biotechnology of mass culturing of Dunaliella for products of commercial interest. In: Cresswell RC, Rees TAV, Shah N, editors. Algal and cyanobacterial technology. London: Longman; 1987. p. 90-114.

Benemann JR, Kopman BL, Weissman DE, Eisenberg DE, Goebel RP. Development of microalgae harvesting and high rate pond technologies in California. In: Shelef G, Soeder CJ, editors. Algal biomass. Amsterdam: Elsevier; 1980. p. 457.

Bermejo Román R, Talavera EM, Alvarez-Pez JM. Chromatographic purification and characterization of $b$-phycoerythrin from Porphyridium cruentum. Semipreparative HPLC separation and characterization of its subunits. J Chromatogr A 2001;917:135-45.

Bermejo Román R, Alvárez-Pez JM, Acién Fernández FG, Molina Grima E. Recovery of pure $b$-phycoerythrin from the microalga Porphyridium cruentum. J Biotechnol 2002;93:73-85.

Bilanovic D, Shelef G, Sukenik A. Flocculation of microalgae with cationic polymers - effects of medium salinity. Biomass $1988 ; 17: 65-76$. 
Blanchemain A, Grizeau D. Increased production of eicosapentaenoic acid by Skeletonema costatum cells after decantation at low temperature. Biotechnol Tech 1999;13:497-501.

Borowitzka MA. Microalgae as sources of fine chemicals. Microbiol Sci 1986;3:372-5.

Borowitzka MA. Closed algal photobioreactors: design considerations for large-scale systems. J Mar Biotechnol 1996;4: $185-91$.

Borowitzka MA. Microalgae for aquaculture: opportunities and constraints. J Appl Phycol 1997;9:393-401.

Borowitzka MA. Commercial production of microalgae: ponds, tanks, tubes and fermenters. J Biotechnol 1999;70:313-21.

Bubrick P. Production of astaxanthin from Haematococcus. Biores Technol 1991;38:237-9.

Cannell RJP. Algal biotechnology. Appl Biochem Biotechnol 1990;26:85-105.

Cartens M, Molina E, Robles A, Giménez A, Ibáñez MJ. Eicosapentaenoic acid (20:4n-3) from the marine microalga Phaeodactylum tricornutum. J Am Oil Chem Soc 1996;73:1025-31.

Chisti Y. Strategies in downstream processing. In: Subramanian G, editor. Bioseparation and bioprocessing: a handbook vol. 2. New York: Wiley-VCH; 1998. p. 3-30.

Chisti Y. Shear sensitivity. In: Flickinger MC, Drew SW, editors. Encyclopedia of bioprocess technology: fermentation, biocatalysis, and bioseparation, vol. 5. New York: Wiley; 1999. p. 2379-406.

Chisti Y, Moo-Young M. Disruption of microbial cells for intracellular products. Enzyme Microb Technol 1986;8:194-204.

Chisti Y, Moo-Young M. Fermentation technology, bioprocessing, scale-up and manufacture. In: Moses M, Cape RE, editors. Biotechnology: the science and the business. New York: Harwood Academic Publishers; 1991. p. 167-209.

Cohen JM, Rourke GA, Woodward RL. Natural and synthetic polyelectrolytes as coagulants and coagulant aids. Bull U S Dept Health, Educ Welf [Robert A Taft Sanitary Eng Center, Cinncinati, OH, December].

Dodd JC. Algae production and harvesting from animal wastewaters. Agric Wastes 1979;1:23-37.

D'Souza FML, Lecossois D, Heasman MP, Diemar JA, Jackson CJ, Pendrey RC. Evaluation of centrifuged microalgae concentrates as diets for Penaeus monodon Fabricius larvae. Aquacult Res 2000;31:661-70.

Dunstan GA, Vokman JK, Jeffrey SW, Barret SM. Biochemical composition of microalgae from the green algal classes Chlorophyceae and Parasinophyceae: 2. Lipid classes and fatty acid. J Exp Mar Biol Ecol 1992;161:115-34.

Elmaleh S, Coma J, Grasmick A, Bourgade L. Magnesium induced algal flocculation in a fluidized bed. Water Sci Technol 1991;23:1695-702.

Giménez Giménez A, Ibáñez MJ, Robles A, Molina E, García S, Esteban L. Downstream processing and purification of eicosapentaenoic (20:5n-3) and arachidonic acids (20:4n-6) from the microalga Porphyridium cruentum. Bioseparation 1998;7:89-99.

Golueke CG, Oswald WJ. Harvesting and processing sewage grown planktonic algae. J Water Pollut Control Fed 1965;37: 471-98.

Gudin C, Chaumont D. Cell fragility, the key problem of microalgae mass production in closed photobioreactors. Bioresour Technol 1991;38:141-51.

Gudin C, Therpenier C. Bioconversion of solar energy into organic chemicals by microalgae. Adv Biotechnol Processes 1986;6:73-110.

Heasman M, Diemar J, O' Connor W, Sushames T, Foulkes L, Nell JA. Development of extended shelf-life microalgae concentrate diets harvested by centrifugation for bivalve molluses - a summary. Aquacult Res 2000;31(8-9):637-59.

Hedenskog G, Enebo L, Vendlová J, Prokes BTI. Investigation of some methods for increasing the digestibility in vitro of microalgae. Biotechnol Bioeng 1969;11:37-51.

Hee-Mock O, Lee SJ, Park MH, Kim HS, Kim HC, Yoon JH, et al. Harvesting of Chlorella vulgaris using a bioflocculant from Paenibacillus sp. AM49. Biotechnol Lett 2001;23:1229-34.

Humphreys K. Jelen's cost and optimization engineering. 3rd ed. New York: McGraw-Hill; 1991.

Ibáñez González MJ, Robles Medina A, Molina Grima E, Giménez Giménez A, Carstens M, Esteban Cerdan L. Optimization of fatty acid extraction from Phaeodactylum tricornutum UTEX 640 biomass. J Am Oil Chem Soc 1998;75:1735-40.

Jiang J.-Q., Graham NJD, Harward C. Comparison of polyferric sulphate with other coagulants for the removal of algae and algae-derived organic matter. Water Sci Technol 1993;27:221-30.

Kaya VM, Picard G. Stability of chitosan gel as entrapment matrix of viable Scenedesmus bicellularis cells immobilized on screens for tertiary treatment of wastewater. Bioresour Technol 1996;56:147-55.

Koopman B, Lincoln EP. Autoflotation harvesting of algae from high rate pond effluents. Agric Wastes 1983;5:231-46.

Lavoie A, de la Noue J. Harvesting microalgae with chitosan. J World Maricult Soc 1983;14:685-94.

Lee SJ, Kim SB, Kim JE, Kwon GS, Yoon BD, Oh HM. Effects of harvesting method and growth stage on the flocculation of the green alga Botryococcus braunii. Lett Appl Microbiol 1998;27:14-8.

Li HB, Chen F, Zhang TY, Yang FQ, Xu GQ. Preparative isolation and purification of lutein from the microalga Chlorella vulgaris by high-speed counter-current chromatography. J Chromatogr A 2001;905:151-5. 
Lim GB, Lee SY, Lee EK, Haam SJ, Kim WS. Separation of astaxanthin from red yeast Phaffia rhodozyma by supercritical carbon dioxide extraction. Biochem Eng J 2002;11:181-7.

Lincoln EP. Resource recovery with microalgae. Arch Hydrobiol 1985;20:25-34.

Lubian LM. Concentrating cultured marine microalgae with chitosan. Aquacult Eng 1989;8:257-65.

MacKay D, Salusbury T. Choosing between centrifugation and crossflow microfiltration. Chem Eng (Lond) 1988;477: 45-50.

McCausland MA, Brown MR, Barrett SM, Diemar JA, Heasman MP. Evaluation of live microalgae and microbial pastes as supplementary food for juvenile Pacific oyster (Crassostrea gigas). Aquaculture 1999;174:323-42.

McGarry MG. Alga flocculation with aluminium sulfate and polyelectrolytes. J Water Pollut Control Fed 1970;42:R191-201.

Mendes-Pinto MM, Raposo MFJ, Bowen J, Young AJ, Morais R. Evaluation of different cell disruption processes on encysted cells of Haematococcus pluvialis: effects on astaxanthin recovery and implications for bio-availability. J Appl Phycol 2001;13:19-24.

Middelberg APJ. The release of intracellular bioproducts. In: Subramanian G, editor. Bioseparation and bioprocessing: a handbook, vol. 2. Weinheim: Wiley-VCH; 1994. p. 131-64.

Mohn FH. Improved technologies for the harvesting and processing of microalgae and their impact on production costs. Arch Hydrobiol, Beih Ergeb Limnol 1978;1:228-53.

Mohn FH. Experiences and strategies in the recovery of biomass from mass cultures of microalgae. In: Shelef G, Soeder CJ, editors. Algae biomass. Amsterdam: Elsevier; 1980. p. 547-71.

Molina Grima E. Microalgae, mass culture methods. In: Flickinger MC, Drew SW, editors. Encyclopedia of bioprocess technology: fermentation, biocatalysis and bioseparation, vol. 3. New York: Wiley; 1999. p. 1753-69.

Molina Grima E, Robles Medina A, Giménez Giménez A, Sánchez Pérez JA, García Camacho F, García Sánchez JL. Comparison between extraction of lipids and fatty acids from microalgal biomass. J Am Oil Chem Soc 1994;71:955-9.

Molina Grima E, Robles Medina A, Giménez Giménez A, Ibañez González MJ. Gram-scale purification of eicosapentaenoic acid (EPA 20:5n3) from wet Phaeodactylum tricornutum UTEX 640 biomass. J Appl Phycol 1996;8:359-67.

Molina Grima E, Acién Fernández FG, Garcia Camacho F, Chisti Y. Photobioreactors: light regime, mass transfer, and scale-up. J Biotechnol 1999;70:231-48.

Moraine R, Shelef G, Sandbank F, Bar-Moshe Z, Shvartzbard I. Recovery of sewage borne algae: flocculation and centrifugation technique. In: Shelef G, Soeder CJ, editors. Algae biomass. Amsterdam: Elsevier; 1980. p. 531-46.

Morales J, de la Noue J, Picard G. Harvesting marine microalgae species by chitosan flocculation. Aquaculture Eng 1985;4: $257-70$.

Nigam BP, Ramanathan PK, Venkataraman LV. Application of chitosan as a flocculant for the cultures of the green alga: Scenedesmus acutus. Arch Hydrobiol 1980;88:378-87.

Peet M, Brind J, Ramchand CN, Shah S, Vankar GK. Two double-blind placebo-controlled pilot studies of eicosapentaenoic acid in the treatment of schizophrenia. Schizophr Res 2001;49:243-51.

Peet M, Horrobin DFEPA Multicentre Study Group. A dose-ranging exploratory study of the effects of ethyl-eicosapentaenoate in patients with persistent schizophrenic symptoms. J Psychiatr Res 2002;36:7-18.

Peters MS, Timmerhaus KD. Plant design and economics for chemical engineers. 4th ed. New York: McGraw-Hill; 1991.

Petrusevski B, Bolier G, Van Bremen AN, Alaerts GJ. Tangential flow filtration: a method to concentrate freshwater algae. Water Res 1995;29:1419-24.

Pulz O. Photobioreactors: production systems for phototrophic microorganisms. Appl Microbiol Biotechnol 2001;57:287-93.

Pulz O, Scheinbenbogen K. Photobioreactors: design and performance with respect to light energy input. Adv Biochem Eng Biotechnol 1998;59:123-52.

Pulz O, Scheibenbogen K, Gross W. Biotechnology with cyanobacteria and microalgae. In: Rehm H.-J., Reed G, editors. Biotechnology, vol. 10. Weinheim: Wiley-VCH; 2001. p. 105-36.

Pushparaj B, Pelosi E, Torzillo G, Materassi R. Microbial biomass recovery using a synthetic cationic polymer. Bioresour Technol 1993;43:59-62.

Richmond A. Microalgae of economic potential. In: Richmond A, editor. CRC handbook of microalgal mass culture. Boca Raton: CRC Press; 1986. p. 199-243.

Richmond A, Becker EW. Technological aspects of mass cultivation, a general outline. In: Richmond A, editor. CRC handbook of microalgal mass culture. Boca Raton: CRC Press; 1986. p. 245-63.

Robles Medina A, Giménez Giménez A, García Camacho F, Sánchez Pérez JA, Molina Grima E, Contreras Gómez A. Concentration and purification of stearidonic, eicosapentaenoic, and docosahexaenoic acids from cod liver oil and the marine microalga Isochrysis galbana. J Am Oil Chem Soc 1995;72:575-83.

Rodríguez-Ruiz J, Belarbi E.-H., García Sánchez JL, López Alonso D. Rapid simultaneous lipids extraction and transesterification for fatty acid analysis. Biotechnol Tech 1998;12:689-91. 
Rossignol N, Vandanjon L, Jaouen P, Quemeneur F. Membrane technology for the continuous separation microalgae/culture medium: compared performances of cross-flow microfiltration and ultrafiltration. Aquacult Eng 1999;20:191-208.

Ruane, M. Extraction of caroteniferous materials from algae. Australian patent No. 7,239,574 (1977).

Sánchez Mirón A, Contreras Gómez A, García Camacho F, Molina Grima E, Chisti Y. Comparative evaluation of compact photobioreactors for large-scale monoculture of microalgae. J Biotechnol 1999;70:249-70.

Shelef G. Photosynthetic biomass production from sewage. Arch Hydrobiol Beih 1978;11:3-14.

Suh HH, Kwon GS, Lee CH, Kim HS, Oh HM, Yoon BD. Characterization of bioflocculant produced by Bacillus sp. DP-152. J Ferment Bioeng 1997;84:108-12.

Tenney MW, Echelberger WF, Schuessler RG, Pavoni JL. Algal flocculation with synthetic organic polyelectrolytes. Appl Bacteriol 1969;18:965-71.

Terry KL, Raymond LP. System design for the autotrophic production of microalgae. Enzyme Microb Technol 1985;7:474-87.

Tilton RC, Murphy J, Dixon JK. The flocculation of algae with synthetic polymeric flocculants. Water Res 1972;6:155-64.

Tredici MR. Bioreactors, photo. In: Flickinger MC, Drew SW, editors. Encyclopedia of bioprocess technology: fermentation, biocatalysis and bioseparation, vol. 1. New York: Wiley; 1999. p. 395-419.

Venkataraman LV. New possibility for microalgae production and utilisation in India. Arch Hydrobiol Beih 1978;11:199-210.

Yahi H, Elmaleh S, Coma J. Algal flocculation-sedimentation by $\mathrm{pH}$ increase in a continuous reactor. Water Sci Technol 1994;30:259-67. 